\title{
NEW ASPECTS OF MULTINATIONAL FIRMS ACTIVITIES IN THE CONTEXT OF GLOBAL FINANCIAL CRISIS: EXPERIENCE IN ITALY
}

\author{
Adalgiso Amendola ${ }^{1}$, Anna Ferragina ${ }^{2}$, Rosanna Pittiglio ${ }^{3}$, Filippo Reganati ${ }^{4}$ \\ ${ }^{1,2}$ University of Salerno, Via di Ponte don Melillo, snc, 84084, Fisciano (SA), Italy,

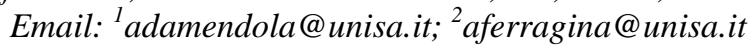 \\ ${ }^{3}$ Second University of Napoli, Corso Gran Priorato di Malta, 81043, Capua (CE ), Italy, \\ Email: rosanna.pittiglio@unina2.it \\ ${ }^{4}$ Sapienza, University of Roma, Via Salaria, 112, 00185, Roma (RM), Italy, \\ Email: filippo.reganati@uniroma1.it
}

\begin{abstract}
In this paper authors examine the effects of ownership status and exporting activity on the likelihood of survival for firms operating in the Italian manufacturing during the recent economic crisis. In particular, they aim to answer the following two main questions: What is the direct impact of being an exporter or a multinational enterprise (both domestic and foreign) on the likelihood of Italian firm survival? Do globally engaged firms react to the severity of the economic crisis differently from national-non exporter firms?

Using an original database for the period 2002-2010 and estimating a conditional Probit model based on a wide range of relevant variables, we find strong evidence that during the recent global crisis exporting firms exhibit lower exiting rates than non exporting ones, while domestic multinationals have higher exit risks than those of domestic firms. Also, affiliates of foreign firms do not behave differently from national firms.
\end{abstract}

Keywords: financial crisis, trade, multinational firms, firm exit.

Jel classification: C41, F1, F23, L2

\section{Introduction}

The inadequate performance of financial and real markets after the 2008 global crisis has led to limited entry of new firms and higher firm exit. This framework provides a kind of ideal natural experiment to investigate firm survival.

The specific contribution of this paper is to investigate whether Italian firms engaged in global markets by exports and foreign direct investment (FDI) exhibited different survival performance in the recent crisis with respect to firms not involved in these activities.

The analysis of the determinants of firm survival has long been a key objective of research in different fields. The specific role of access to foreign markets, both through exports and FDI, is at the core of a rising recent literature on firm survival (Greenaway et al. 2008; Wagner 2011). Some recent papers have also found evidence that globally engaged firms exhibit lower sensitivity to financial constraints than purely domestic firms (Guariglia, Mateut 2005; Blalock et al. 2008; Greenaway et al. 2007; Bridges, Guariglia 2008; Görg, Spaliara 2009).
However, quite few studies have tried to address how global engagement influences firm performances in the context of an economic slowdown. This scant literature has mostly focused on the role that foreign multinationals (FMNEs) play in an economic crisis and is mostly based on the Asian financial crisis (McAleese, Counahan 1979; Desai et al. 2004; Desai et al. 2008) or on past country specific slowdowns such as in Chile at the end of the 1990s (Alvarez, Görg 2011) and in Portugal in the early 1990s and 2000s (Varum, Rocha 2011). To the best of our knowledge only three recent studies have focused on the behaviour of foreign investors in the recent global crisis in a cross national framework (Tong, Wei 2010; Alfaro, Chen 2011) and, as an example for Ireland, at national level (Godart et al. 2011). However, an overlooked issue in this literature is the behaviour of exporters and domestic multinationals (DMNEs) in a crisis context.

The first contribution of our paper is to fill this void in the literature focusing on the exit behaviour of firms which are exporters or multinational enterprises (both DMNEs and FMNEs) 
within the context of the recent international crisis. The second contribution of this study is to deepening a rising firm level literature on the impact of the international crisis on Italian firms. So far, empirical evidence has explored the impact of firm size and export propensity (Bugamelli et al. 2009), of product and process innovation (Antonioli et al 2011) and of firm labour cost adjustment processes (Cingano et al. 2010; Fabiani, Sabbatini 2011) on firm growth over the crisis.

We use an original database, obtained by matching and merging three firm-level datasets: Capitalia, AIDA and Mint-Italy. The empirical analysis is carried out in two steps. Firstly, we describe the statistical differences in the likelihood of survival comparing different firm characteristics between the sample of firms which do not fail over the whole period (2004-2010), with two other groups: the firms which exit between 2004 and 2008, and those which exit over 2008-2010, i.e. during the global crisis. Secondly, using a Probit model we estimate the determinants of firms' probability of failing before the crisis and after it, as effect of firm internationalisation (exports, inward and outward FDI), controlling for a wide set of other variables at firm level (size, age, productivity, innovation, financial constraints such as profit margin, collateral, solvency ratio and debt with banks over turnover) and at industry level (technological intensity of the sectors using a Pavitt taxonomy, international specialisation).

We find different characteristics for surviving and exiting firms before and after the crisis shock. More specifically, our results show that during the crisis exporters perform much better than non exporters, while DMNEs are more likely to exit than domestic firms and FMNEs show a pattern not significantly different with respect to national firms. As for the other firm characteristics, we find mixed results with respect to our a priori. On the one hand, we find evidence that financial health and innovation performances matter during the crisis: surviving firms have higher collateral and solvency, are less indebted with the banks and belong to a high technology sector (according to Pavitt taxonomy and with respect to the reference category of specialised suppliers). Conversely, we find that unexpectedly the higher firm size and age do not reduce exit probabilities during the crisis, unlike before it.

The paper is structured as follows. In section 2 we lay out the theoretical background and the research hypotheses. In section 3 we sketch out the dataset construction, some descriptive statistics and the variables used. Finally, in section 4 we analyse the econometric methodology and present our results.

\section{Globally engaged firms and survival during an economic slowdown: a brief survey}

In the recent literature on firm survival, export activities and international production are the most debated factors. However, despite there is now a wide theoretical and empirical literature on the relationship between firm global activities and firm performance (Görg, Strobl 2003; Kimura, Fujii 2003; Bernard, Sjöholm 2003; Ozler, Taymaz 2004; Esteve Pérez et al. 2004; Alvarez, Görg 2009; Ferragina et al. 2010; Ferragina et al. 2011) there are still few investigations on how these relationships work during an economic slowdown.

Why should we expect that globally engaged firms behave differently in the context of an economic slowdown?

\section{a) To be exporter during an economic slowdown} Following the New-New Trade Theory exporting firms are more productive, have higher technological, managerial and human capabilities and, therefore, have higher capacity to face adverse external conditions (Melitz 2003). Besides, exporting can be considered as a form of risk diversification through spread of sales over different markets with different business cycle conditions or in a different phase of the product cycle. Therefore, exports might provide a chance to substitute sales at home by sales abroad when a negative demand shock hits the home market and would force a firm to close down otherwise. However, there are also reasons to expect exporters to be more vulnerable to the negative effects of an economic crisis, especially if this is global and does not allow to take advantage of different market conditions. For instance, exporters might be especially affected by higher sunk costs and be more concentrated on economies of scale and as such less flexible in adapting to an economic downturn. Furthermore, they might be more reliant on credit and bank lending and they might be paying higher interest rates. As a result the predictions are ambiguous: exporting firms might be more able to sustain their survival and employment level and counteract the negative effects of the crisis, helping to stabilize the economy, but on the contrary they might also be more vulnerable. The empirical evidence on these matters is still scarce and concentrated on the context of the East Asian financial crisis (Sato 2000; ter Wengel, Rodriguez 2006). 


\section{b) To be multinational during an economic slowdown}

There are ambiguous a priori also on the way MNEs react to an economic shock. Why should we expect a different behaviour from multinationals with respect to domestic firms? First of all, MNEs have access to both internal and international financial markets, which allows them to diversify their sources of financing and the associated risks and also allows foreign affiliates to be less dependent on host capital markets in their operations as they may obtain credit from their multinational parents. This is crucial especially under a credit tight imposed by global financial crisis. Secondly, because MNEs enjoy less bankruptcy risk and adopt international standards in terms of product quality, they find it easier to gain access to domestic banks (Colombo 2001; Harrison, McMillan 2003). Thirdly, there is the argument of substantial sunk costs of entry into foreign market and even more of investing abroad, and the strong investment in long-term relationships and accumulation of firm-specific skills in foreign markets, which may also explain why MNEs are unlikely to reply aggressively to short term changes in host country conditions and be more able to adapt themselves to the hostile environment. However, there are also reasons to expect MNEs to be more reactive to the negative effects of an economic crisis, and therefore, act as "unstabilising agents". In the case of multinationals, these can move production facilities easily between different countries (the "footloose behaviour" hypothesis).

There is a certain amount of empirical evidence on the specific reaction of foreign firms in terms of both exit behaviour and growth patterns. According to the role played by MNEs, these studies can be summarized into three different groups, which respectively find: 1) a stabilising role 2) a destabilising role; 3 ) no evidence of a (de) stabilising role (see table 1 ).

A discrete number of studies find that MNEs exhibit a better reaction to crises than domestic firms (stabilising role). Many of them stress upon the financial issues. Desai et al. (2004) show that multinational affiliates substitute internal borrowing for costly external finance when facing adverse capital market conditions. In a more recent paper, Desai et al. (2008) also find that US multinationals located in emerging markets increase operations more than domestic firms in the presence of a currency crisis and they argue that this is due to multinationals being less financially constrained than domestic firms.
Table 1. Literature on the potential impact of foreign MNEs and SMEs exporting firms over a crisis

\begin{tabular}{|l|l|}
\hline \multicolumn{1}{|c|}{ Results } & \multicolumn{1}{c|}{ References } \\
\hline $\begin{array}{l}\text { FMNEs as } \\
\text { "stabilizing” agents }\end{array}$ & $\begin{array}{l}\text { Fukao 2001; Athukorala 2003; } \\
\text { Wang } \text { et al. 2005; Blalock et } \\
\text { al. 2005; Chung } \text { et al. 2005; } \\
\text { Narioko } \text { et al. 2007; Desai } \text { et al } \\
\text { 2004 ; Desai } \text { et al 2008; Alfaro } \\
\text { et al. 2011; Tong et al. 2010 }\end{array}$ \\
\hline $\begin{array}{l}\text { FMNEs as } \\
\text { "unstabilising” agents }\end{array}$ & $\begin{array}{l}\text { Flamm 1984; Lipsey 2001; Gorg } \\
\text { et al. 2003; Alvarez } \text { et al. 2009 }\end{array}$ \\
\hline $\begin{array}{l}\text { No evidence of a } \\
\text { (de)stabilizing role of } \\
\text { FMNEs }\end{array}$ & $\begin{array}{l}\text { McAleese } \text { et al. 1979; Varum } \text { et } \\
\text { al. 2011; Alvarez et al. 2011; } \\
\text { Godart } \text { et al. 2011 }\end{array}$ \\
\hline $\begin{array}{l}\text { Exporting SMEs bet- } \\
\text { ter able to adjust }\end{array}$ & Sato 2000; ter Wengel et al. 2006 \\
\hline
\end{tabular}

Blalock et al. (2008) show that after the 1997 East Asian financial crisis Indonesian exporters with foreign ownership were able to significantly increase their investment, while domestically owned exporting firms were unable to do so due to financing constraints. Focusing on the recent crisis with data on 3,823 firms in 24 emerging countries, Tong and Wei (2010) find that exposure to FDI alleviated liquidity constraints. Fukao (2001) and Wang et al. (2005) emphasise the role of substantial sunk costs in investing abroad in addition to investment, long-term relationships and accumulation of firm-specific skills as the reason why foreign firms are unlikely to reply aggressively to short term changes in host country conditions. Alvarez et al. (2011) point to the same conclusion in their investigation of the response of multinational and domestic firms to an economic downturn in Chile: lower employment reductions over the economic crisis with respect to domestic firms (although they are more likely to exit).

A less optimistic view on multinational behaviour over a crisis (destabilising role) is supported by few studies (Flamm 1984; Lipsey 2001; Gorg, Strobl 2003; Alvarez, Gorg 2009), which suggest that foreign firms introduce higher volatility in the host economy because they move production facilities easily between different countries (the "footloose behaviour" hypothesis).

Finally, there is a third group of studies that do not find any particular difference in the behaviour of MNEs compared to domestic firms during a slowdoun. McAleese and Counahan (1979) for Ireland do not find any difference in employment adjustment between multinational and domestic firms during a recession. Varum e Rocha (2011) examine firm employment and turnover growth over 20 years focusing on economic downturns in Portugal and find no significant differences between domestic and foreign firms. Godart et al. 
(2011) also find that foreign firms are not more likely to leave during the recent crisis than Irish firms.

To sum up, we may conclude that so far the largest empirical evidence is consistent with the hypothesis that foreign multinationals are less affected by an economic crisis and that they are able to act as stabilizer in an economy, while there is less support for the footloose behaviour of foreign multinationals in a crisis.

\section{Data, variables and preliminary empirics}

In this section we present the dataset (section 3.1), the variables specifications and the theoretical a priori with respect to them (section 3.2) and some descriptive statistics (section 3.3).

\subsection{Dataset construction}

The empirical analysis included in this paper has been conducted using a firm level database for the period 2002-2009 resulting from the intersection of three different sources: IX $^{\text {th }}$ Survey on Manufacturing Firms by Capitalia/Unicredit, AIDA (Analisi Informatizzata delle Aziende) and MintItaly, by Bureau Van Dyck.

The IX $^{\text {th }}$ Capitalia survey provides micro evidence about manufacturing companies and covers the period 2001-2003. This survey has been run in 2004 through questionnaires distributed to a sample of 4289 firms with more than 10 employees. However, this database presents two drawbacks. Firstly, most of Capitalia questions refer to the entire threeyear period, rather than to each year. Secondly, it does not provide data on a wide set of financial variables useful for the analysis. Given the limits above mentioned, additional information useful for the aim of the paper come from the rich firm level database AIDA. AIDA collects annual accounts of Italian corporate enterprises and contains information on a wide set of economic and financial variables such as sales, costs and number of employees, value added, fixed tangible assets, start-up year, as well as legal and ownership status.

Variables about internationalization activity of firms are drawn from AIDA, Capitalia and MintItaly. In particular, using the ownership status variable in AIDA we define domestic multinationals (DMNEs) as non foreign-owned firms with a share of direct ownership greater/ equal to 10 percent in firms located in countries other than Italy and foreign multinationals (FMNEs) as Italian firms whose Global Ultimate owner is foreign. Information related to the export activity of the firms is drawn from a merger between Capitalia and Mint-Italy. This latter is a firm level database of
Italian companies, banks and insurance companies with variables on export and import activities. More specifically, the merger between Capitalia and Mint-Italy allowed us to identify the firms in the sample that were exporters over the period 2002-2009.

The legal status (i.e. active, into liquidation, bankruptcy or inactive) allows us to identify the exit of the firm. In this way, we have identified all firms in the Capitalia dataset (with info in 20012003) still alive on January $1^{\text {st }} 2008$ and we have matched them with AIDA information obtaining 4066 firms (that is 94.8 per cent of the Capitalia sample, which includes 4289 firms). Likewise, we have identified firms inactive after the crisis period, i.e. firms inactive on January $1^{\text {st }} 2010$ and, in the same way, firms which survived over 20082010. This kind of dataset is a catch-up panel, where a cross-sectional data set is chosen at some time in the past and then the units of analysis are located in the present by subsequent observations.

\subsection{Variables specification and expected signs}

Following the literature on the determinats of firm survival, in this section we describe the specification and the expected sign of a wide set of variables which we use in our empirical analysis (more details are shown in table 2).

More specifically, we use the following set of variables:

1) Internationalisation variables;

2) Firm structure and performance variables;

3) Firm financial variables;

4) Innovation variables.

\section{1) Internationalisation variables}

- EXPORT is the export dummy variable that takes a value of 1 if firm $i$ is an exporter and 0 otherwise;

- OUTFDI is the domestic multinational ownership dummy that takes a value of 1 if firm $i$ is an Italian owned MNE and 0 otherwise;

- INWFDI is the foreign multinational ownership dummy that takes a value of one 1 if firm $i$ is foreign owned and 0 otherwise.

Following the literature surveyed in section 2, the expected results are ambiguous. We have also considered:

- SPEC which is a dummy that takes a value of one if the 3 digit Ateco Lafay index of specialisation is greater than 0 and 0 otherwise. 


\section{2) Firm structure and performance variables}

- $\quad$ SIZE is given by the number of employees. It is a stylized fact from many empirical studies that the likelihood of firm exit declines with firm size measured by the number of employees (Dunne et al. 1989; Mata, Portugal 1994). There are several reasons suggesting a negative relationship between firm size and the probability of exit. A small size can be interpreted as a proxy variable for a number of unobserved firm characteristics, including disadvantages of scale, higher restrictions on the capital market and in access to labour markets, leading to a higher risk of insolvency and illiquidity for small firms, competition for highly qualified employees, and lower talent of management.

- AGE is defined as the difference between year $t$ and the official year of incorporation of the firm. Since older firms are more likely to possess a bundle of characteristics that have helped them to prevent exit in the past, we expect that have a lower chance to exit. This is coherent with selection models (Jovanovic 1982), where firms go through a process of learning about their relative efficiency and market competitiveness, and in line with a large number of empirical papers which have shown that younger firms are more likely to fail (e.g., Mata et al. 1994; Audretsch, Mahmood 1995; Disney et al. 2003).

- PROD is labour productivity, namely net value added per employee. Since several theoretical models describing the dynamics of industries with heterogeneous firms (Jovanovic 1982; Hopenhayn 1992) predict that the exit of firms is motivated to a large extent by productivity differences at the firm level, we expect that the survival rates of firms are higher within more productive firms.

\section{3) Financial variables}

- $\quad$ PROFIT is the operating margin on total sales. Higher profits reduce exiters, while lower profits stimulate the decision to exit; so we expect a positive impact of the operating profit ratio on the likelihood of survival.

- SOLVENCY defines the solvency ratio (shareholder's funds/total assets), which is an indicator of the liquid assets of the firm. We expect to find that more solvent firms face a lower likelihood of failure.
Table 2. Definition of variables, data sources and expected relationships

\begin{tabular}{|c|c|c|c|c|}
\hline Category & Variables & Description & Source & $\begin{array}{l}\text { Exp. } \\
\text { sign }\end{array}$ \\
\hline \multirow{3}{*}{ 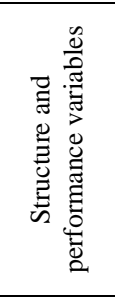 } & Size & $\begin{array}{l}\text { Firm size measured by } \\
\text { the number of employ- } \\
\text { ees. }\end{array}$ & Aida & - \\
\hline & Age & $\begin{array}{l}\text { Firm age measured by } \\
\text { the number of years } \\
\text { since establishment. }\end{array}$ & Aida & - \\
\hline & Prod & $\begin{array}{l}\text { Firm productivity meas- } \\
\text { ured by value added per } \\
\text { employee }\end{array}$ & Aida & - \\
\hline \multirow{4}{*}{ 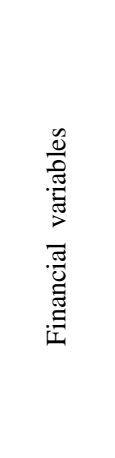 } & Profit & $\begin{array}{l}\text { Firm profit before tax } \\
\text { over turnover }(\%)\end{array}$ & Aida & - \\
\hline & Solvency & $\begin{array}{l}\text { Company's post-tax net } \\
\text { profit and depreciation } \\
\text { divided by the quantity } \\
\text { of long-term and short- } \\
\text { term liabilities (\%) }\end{array}$ & Aida & - \\
\hline & Collateral & $\begin{array}{l}\text { Firm ratio of its tangible } \\
\text { assets to its total assets } \\
(\%,)\end{array}$ & Aida & - \\
\hline & $\begin{array}{l}\text { Debts } \\
\text { banks }\end{array}$ & $\begin{array}{l}\text { Firm short and long term } \\
\text { debts with banks over } \\
\text { turnover }(\%)\end{array}$ & Aida & + \\
\hline \multirow{4}{*}{ 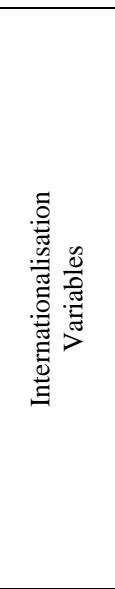 } & Inwfdi & $\begin{array}{l}\text { Foreign ownership } \\
\text { dummy that takes on the } \\
\text { value } 1 \text { if the firm is } \\
\text { foreign-owned, } 0 \text { other- } \\
\text { wise }\end{array}$ & Aida & $+/-$ \\
\hline & Outfdi & $\begin{array}{l}\text { Domestic multinational } \\
\text { ownership dummy that } \\
\text { takes on the value } 1 \text { if } \\
\text { the firm is an Italian } \\
\text { owned-MNE, } 0 \text { other- } \\
\text { wise. }\end{array}$ & Aida & $+/-$ \\
\hline & Export & $\begin{array}{l}\text { Dummy variable equal } \\
\text { to } 1 \text { if the firm exports } \\
\text { over the entire period }\end{array}$ & $\begin{array}{l}\text { Mint- } \\
\text { Italy }\end{array}$ & - \\
\hline & Spec & $\begin{array}{c}\text { Dummy }=1 \text { if } 3 \text { digit } \\
\text { Ateco Lafay index of } \\
\text { specialisation }>0 \text { oth- } \\
\text { erwise }=0\end{array}$ & OECD & - \\
\hline \multirow{2}{*}{ 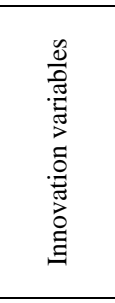 } & $\mathrm{RD}$ & $\begin{array}{c}\text { R\&D intensity defined } \\
\text { as the ratio of } R \& D \\
\text { expenditure on sales }\end{array}$ & Aida & $+/-$ \\
\hline & Pavitt & $\begin{array}{l}\text { PAVITT } p \text {-1 macrosector } \\
\text { dummies }(p=1, . ., 4) \text { for } \\
\text { firms belonging to Tra- } \\
\text { ditional (1), Specialised } \\
\text { (2), Scale (3) and High- } \\
\text { Tech (4) industries }\end{array}$ & Capitalia & $+/-$ \\
\hline \multirow{2}{*}{ 鴶兽 } & $\begin{array}{l}\text { Location } \\
\text { dummy }\end{array}$ & $\begin{array}{l}\text { Dummy = } 1 \text { for firms } \\
\text { located in Southern } \\
\text { areas* and } 0 \text { otherwise. }\end{array}$ & Aida & \\
\hline & $\begin{array}{l}\text { Ateco } \\
\text { sectors }\end{array}$ & $\begin{array}{l}2 \text { digit Ateco } 2002 \text { clas- } \\
\text { sification }\end{array}$ & Istat & \\
\hline
\end{tabular}

- COLLATERAL, given by the ratio of firm tangible assets to its total assets, is expected to have an important impact in terms of lowering failure probabilities.

- DEBTS BANKS can be associated with a worse balance sheet situation, increasing moral hazard and adverse selection problems. Hence, we should expect a positive relationship between higher leverage and the probability of exit as some empirical studies have 
found (Becchetti et al. 2002; Bunn et al. 2003; Fotopoulos et al. 2000; Vartia 2004; Bridges et al. 2008). On the other hand, as a high rate of leverage can also be seen as an indicator of a good credit standing and high borrowing capacity of firms, we expect an ambiguous sign between leverage and the probability of exit.

\section{4) Innovation variables}

- $\quad$ R\&D (research \& development intensity) is defined as the ratio of $R \& D$ expenditure on sales. According to the resource-based literature (Barney et al. 2001), the chances of survival greatly depend on the ability of firms to develop specific capabilities, which in turn may be improved by investing in R\&D. However, R\&D activities are usually associated with uncertainty and so firms investing in research may suffer a higher failure risk.

- PAVITT are four macrosector dummies which indicate clusters of innovation at industry level. Previous work examining survival conditions of new entrants at the industry level (Audretsch et al. 1995; Audretsch et al. 2000) have found exit rates to be greater in R\&D intensive industries given that the competition environment is tougher. However, Kimura and Fujii (2003) have found that $R \& D$ activities raise firms' survival probabilities.

\subsection{Descriptive statistics}

Table 3 contains the mean of our sets of variables distinguished by three groups of firms: a) firms which do not fail over the whole period (2004-2010), b) firms which exit before the crisis (2004-2008), and c) firms which exit during the crisis (2008-2010).

Statistically comparing the mean differences for our variables of interest related to global engagement, we see that while surviving firm are more likely to be globally engaged via exports (more than $50 \%$ ) than their failed counterparts over both periods (only 4 and $2 \%$ on average are exporters respectively within the two groups of failed firms), subsidiaries of foreign firms are less likely to exit before the crisis but they have not a significantly different probability of exiting than domestic owned firms over the crisis. Domestic multinationals indeed are more likely to exit before the crisis while they also have not a significantly different probability than domestic non multinational firms over the crisis.
Table 3. Descriptive statistics: variable means (2007)

\begin{tabular}{|c|c|c|c|c|c|c|}
\hline & $\begin{array}{c}\text { Sur- } \\
\text { viving } \\
\text { firms }\end{array}$ & $\begin{array}{c}\text { Firms } \\
\text { exited } \\
\text { over } \\
2002- \\
2007 \\
\end{array}$ & $\begin{array}{c}\text { Firms } \\
\text { exited } \\
\text { over } \\
2008- \\
2010 \\
\end{array}$ & $\begin{array}{c}\text { Diff } \\
\text { mean } \\
\text { test }\end{array}$ & $\begin{array}{c}\text { Diff } \\
\text { mean } \\
\text { test }\end{array}$ & $\begin{array}{c}\text { Diff } \\
\text { mean } \\
\text { test }\end{array}$ \\
\hline & $\begin{array}{c}N=3696 \\
(0)\end{array}$ & $\begin{array}{c}N=89 \\
(1)\end{array}$ & $\begin{array}{c}N=281 \\
\text { (2) }\end{array}$ & $(0)-(1)$ & $(0)-(2)$ & (1)-(2) \\
\hline Age & 28.99 & 23.19 & 26.17 & $3.49 a$ & $2.91 a$ & -1.68 \\
\hline Size & 144.27 & 28.97 & 113.57 & $1.89 b$ & 1.05 & -2.74 \\
\hline Prod & 61650 & 21264 & 31235 & $3.49 a$ & $7.43 a$ & -0.65 \\
\hline$R D$ & 0.005 & 0.003 & 0.007 & 0.49 & -0.81 & -0.87 \\
\hline Profit & 4.01 & -51.05 & -21.29 & $9.09 a$ & $9.30 a$ & -1.25 \\
\hline Collateral & 0.76 & 0.62 & 0.7 & $3.31 a$ & $3.13 a$ & -1.4 \\
\hline $\begin{array}{l}\text { Debts } \\
\text { banks }\end{array}$ & 22.87 & 7.15 & 28.68 & $3.32 a$ & $-3.30 a$ & $-3.84 a$ \\
\hline Solvency & 28.86 & 37.80 & 19.72 & $-2.34 a$ & $5.74 a$ & $2.84 a$ \\
\hline Export & 0.51 & 0.04 & 0.02 & $8.81 a$ & $16.43 a$ & 1.19 \\
\hline Inwfdi & 0.92 & 0.99 & 0.92 & $-2.42 b$ & -0.19 & $2.29 b$ \\
\hline Outfdi & 0.04 & 0 & 0.02 & $1.89 c$ & 1.47 & -1.39 \\
\hline Spec & 0.56 & 0.64 & 0.57 & -1.46 & -0.33 & 1.13 \\
\hline Pavitt 1 & 0.50 & 0.65 & 0.53 & $-2.73 a$ & -0.93 & -1.16 \\
\hline Pavitt 2 & 0.18 & 0.13 & 0.19 & 1.02 & -0.5 & -1.16 \\
\hline Pavitt 3 & 0.28 & 0.16 & 0.23 & $2.52 a$ & 1.68 & -1.48 \\
\hline Pavitt 4 & 0.04 & 0.06 & 0.05 & -0.75 & -0.49 & 0.38 \\
\hline $\begin{array}{l}\text { Centre- } \\
\text { north area }\end{array}$ & 0.84 & 0.86 & 0.83 & -0.53 & 0.68 & -0.80 \\
\hline $\begin{array}{l}\text { Southern } \\
\text { area }\end{array}$ & 0.15 & 0.13 & 0.17 & 0.53 & -0.68 & 0.80 \\
\hline
\end{tabular}

To briefly summing up the other results of table 3 , it appears that on average, younger firms, with lower innovation and higher financial constraints appear to have experienced significantly higher failure risks with respect to not failing firms during the crisis. Besides, firms failed over the crisis compared with those failed before it, show a significantly higher size and debt with banks and a lower solvency. However, in the next section we turn to a conditional analysis of firms' failure to check for the exit determinants related to global engagement holding all the other factor constants.

\section{Econometric Methodology and Results}

\subsection{Estimates of the exit rates: the model}

In this study we model the effects of international production variables and exporting activity on the probability of firm survival and we try to estimate if being globally engaged allows firms to react differently to the severity of the economic crisis compared to other firms.

So, we first build a firm exit variable for 20022007 which is equal to 0 if a firm is active over the 
whole period and 1 otherwise (pre-crisis exit). Then, we consider firms which exited over 20082010 and we build an exit variable which is equal to 0 if a firm is active in that period and 1 otherwise (exit over the crisis). Hence, we estimate the probability of failure of a firm (exit dummies) before 2008 and during the crisis (2008-2010) as a function of firm international engagement, controlling for a wide set of firms' and sector characteristics taken at the beginning of the period in which the failure occurred. With this analysis we may also check whether some firm characteristics played a different impact on exit before and during the crisis, respectively.

In line with the literature (e.g., Greenaway et al. 2008; Zingales 1998) we use a maximum likelihood probit model of the firm's survival prospects based on a range of relevant variables.

We observe the company status variable $\left(y_{i t}\right)$, which is either failure $\left(y_{i}=1\right)$ or survival $\left(y_{i}=0\right)$, but we define the dependent variable as a latent variable $y^{*}$, the underlying response variable, which is the probability of failure as a function of the vector of the determinants of failure:

$$
\begin{aligned}
& y_{i}=1 \text { if } y_{i}^{*}>0, \\
& y_{i}=0 \text { if } y_{i}^{*}=0 .
\end{aligned}
$$

The response variable $y^{*}$ is defined by the following regression relationship, in which $y$ is exit in 2002-2008 or exit in 2008-2010, the $x$ variables are taken at the beginning of the exit period (2003 and 2007, respectively), the slope parameters are given by the vector $\beta$ and $\varepsilon_{i t}$ is a normally distributed error term.

$$
y_{i}^{*}=a_{i}+a_{t}+x_{i t} \beta+\delta_{s}+\varepsilon_{i t},
$$

where $\varepsilon_{i t} \sim N\left(0, \sigma^{2}\right)$.

The probability that a firm fails $\left(y_{i}=1\right)$ therefore can be written as:

$$
\begin{gathered}
\operatorname{Pr}\left(y_{i t}=1\right)=\operatorname{Pr}\left(y_{i t}^{*}>0\right) \\
\operatorname{Pr}\left(y_{i t}=1\right)=\operatorname{Pr}\left(x_{i t}^{\prime} \beta+\varepsilon_{i t}+a_{i}+a_{t}>0\right) \\
\operatorname{Pr}\left(y_{i t}=1\right)=\operatorname{Pr}\left(\frac{\varepsilon_{i t}}{\sigma}+a_{i}+a_{t}>-\frac{x_{i t}^{\prime} \beta}{\sigma}\right)
\end{gathered}
$$

Given that $\frac{\varepsilon_{i t}}{\sigma}$ follows a standard normal distribution (mean zero and variance of one) and the probit distribution is symmetric, the probability of failure can be evaluated using the standard normal distribution function, $\Phi($ ) .

$$
\begin{gathered}
\operatorname{Pr}\left(y_{i t}=1\right)=\operatorname{Pr}\left(\frac{\varepsilon_{i t}}{\sigma}+a_{i}+a_{t}<-\frac{x_{i t}^{\prime} \beta}{\sigma}\right) \\
\operatorname{Pr}\left(y_{i t}=1\right)=\Phi\left(\frac{x_{i t}^{\prime} \beta}{\sigma}\right)
\end{gathered}
$$

The main variables of interests are the three internationalisation dummies: 1) the firm exports or not; 2) the firm is an affiliates or not; 3 ) the firm invests abroad or not. The control variables are firm's size, age, productivity and firm's financing characteristics such as profit margin and indicators of liquidity and leverage (leverage, solvency ratio, collateral ratio) (see table 2 for the definition of these variables and expected signs).

Furthermore, we include variables for national specialisation, a location dummy and a set of sectoral (2-digit Ateco 91) dummies $\left(\delta_{s}\right)$ to control for differences in regional economic growth and sector specific changes.

\subsection{Results of the Probit estimates}

Tables 4 and 5 provide the estimation results. The estimated coefficients from a Probit model cannot be used for statements about the size of the effect of a change of the value of an exogenous variable on the value of the endogenous variable (the probability of exit), because the size of this effect depends on both the value of the exogenous variable under consideration and on the values of all the other variables in the model. Therefore, in order to provide some interpretation of the estimated coefficients we also report the marginal changes, evaluated at the sample means for each independent variable. For a continuous variable the marginal effects show the increase in the predicted probability when there is a one-unit increase in the covariate, when the values of all variables in the model are at the mean of the sample used for the estimation of the model. The marginal effect associated with a dummy tells us the change in the predicted probability of failure when the variable changes from zero to one (and when the values of all the other exogenous variables in the model are fixed at the sample mean).

Focusing on firm internationalisation activities via exports, we observe that, both before and after the shock, exporters are significantly more likely to experience reduced exit probabilities, which in terms of the marginal effect, all else held constant, implies a much lower probability of failure for exporting firms: by 2.7 percentage points lower over the pre-crisis period, and by 4.1 over the crisis period. Conversely, the affiliates of a foreign firm do not appear to have a significantly lower failure risk. We also find that Italian multinationals investing abroad during the crisis exhibit higher exit risk while they do not experience lower exit probabilities than domestic firms over the precrisis period.

Looking at the control variables, our results show that larger and older firms, before the crisis 
shock, are significantly more likely to experience lower exit, controlling for other firm and industry characteristics. A $1 \%$ increase in the number of employees reduces the firm's probability of failure by 0.3 percentage points, holding all the other factors constant. This marginal impact need to be compared with the predicted probability of exit, evaluated at the mean of the independent variables, which is 0.8 . Therefore, a marginal impact of 0.3 percentage points implies a reduction in the predicted exit probability by $37.5 \%(0.3 / 0.8)$. Firm age also returns negative coefficients with a significant impact on failure for the group of firms failing before the crisis. The marginal effect of 0.7 percentage points implies a reduction in the predicted exit probability by $87 \%(0.7 / 0.8)$. However, over the crisis larger and older firms have not benefited of higher chances of survival. These results are in contrast with studies showing the relevance of size and age for survival (Dunne et al. 1989; Mata and Portugal 1994 to quote the milestone studies), but in line with other studies such as Audretsch et al. (2000) and Wagner (1994), and more recent studies on firms financial default and size (Bottazzi et al. 2011a; Bottazzi et al. 2011b ), which find no clear-cut nexus between size and the probability of survival.

Productivity shows a more consistent sign and significance: it reduces the risk of failure both before and over the crisis period. In both cases the marginal effect is quite high (0.7 and 0.6), which translates into a reduction of failure probabilities by $87 \%$ before the crisis.

Moving to the role of external finance we observe different results across the two periods: firms exiting over 2004-2008 are not significantly affected by financial constraints. In our estimates profit margin displays a not significant association with the probability of failure, a result we get also in the crisis period, differently from the results shown in Bunn and Redwood (2003) and in Bridges and Guariglia (2008) for UK.

However, while collateral, solvency and debts with banks were not significant determinants of firm failure before the crisis, firms failing over the crisis had lower collateral and solvency ratios and higher indebtedness with banks, which suggests that liquidity constraints turned out to affect positively the likelihood of failure over these years due to more serious financial tights.
Table 4. Probit model: the likelihood of exit before the crisis

\begin{tabular}{|c|c|c|}
\hline & \multicolumn{2}{|c|}{ Firm exit pre-crisis } \\
\hline & Coefficient & $\begin{array}{c}\text { Marginal } \\
\text { effect }\end{array}$ \\
\hline \multirow{2}{*}{ Size } & -0.1431 & -0.0033 \\
\hline & \multicolumn{2}{|c|}{$(-2.65) \mathrm{a}$} \\
\hline \multirow{2}{*}{ Age } & -0.3185 & -0.0073 \\
\hline & \multicolumn{2}{|c|}{$(-3.90) \mathrm{a}$} \\
\hline \multirow{2}{*}{ Prod } & -0.302 & -0.0069 \\
\hline & \multicolumn{2}{|c|}{$(-3.09) \mathrm{a}$} \\
\hline \multirow{2}{*}{ Export } & -1.0059 & -0.0276 \\
\hline & \multicolumn{2}{|c|}{$(-5.96) \mathrm{a}$} \\
\hline \multirow{2}{*}{ Inwfdi } & 0.2256 & 0.0067 \\
\hline & \multicolumn{2}{|c|}{$(0.68)$} \\
\hline \multirow{2}{*}{ Outfdi } & 0.2458 & 0.0073 \\
\hline & \multicolumn{2}{|c|}{$(0.97)$} \\
\hline \multirow{2}{*}{ Collateral } & -0.0239 & -0.0005 \\
\hline & \multicolumn{2}{|c|}{$(-0.10)$} \\
\hline \multirow{2}{*}{ Profit } & 0.0031 & 0.0001 \\
\hline & \multicolumn{2}{|c|}{$(1.04)$} \\
\hline \multirow{2}{*}{ Solvency } & -0.0029 & -0.0001 \\
\hline & \multicolumn{2}{|c|}{$(-0.82)$} \\
\hline \multirow{2}{*}{ Debts banks } & -0.000 & -0.0001 \\
\hline & \multicolumn{2}{|c|}{$(-0.00)$} \\
\hline \multirow{2}{*}{ Spec } & 0.248 & 0.0055 \\
\hline & \multicolumn{2}{|c|}{$(1.54)$} \\
\hline \multirow{2}{*}{$\mathrm{RD}$} & 0.477 & 0.011 \\
\hline & \multicolumn{2}{|c|}{$(0.25)$} \\
\hline \multirow{2}{*}{ Pavitt 1} & 0.2186 & 0.0051 \\
\hline & \multicolumn{2}{|c|}{$(0.44)$} \\
\hline & 0.0527 & 0.0012 \\
\hline Pavitt 3 & \multicolumn{2}{|c|}{$(0.10)$} \\
\hline Dovitt 4 & 0.7114 & 0.0352 \\
\hline Pavilt 4 & & \\
\hline South location dummu & -0.3114 & -0.0057 \\
\hline south location dummy & & \\
\hline Industry 317ummie (2 digit Ateco) & & \\
\hline Number of observations & & \\
\hline Log likelihood & & \\
\hline Pseudo R2 & & \\
\hline Pred. P (at x bar) & & \\
\hline
\end{tabular}

Innovation of firms, measured by R\&D over turnover, turns out to be a weakly significant factor of risk failure, however, belonging to a high technology sector (according to Pavitt taxonomy) is a significant determinant of lower exit over the crisis (1.65 percentage points lower) with respect to firms belonging to the reference category (specialised suppliers). 


\section{EXPERIENCE IN ITALY}

Table 5. Probit model: the likelihood of exit during the crisis

\begin{tabular}{|c|c|c|}
\hline & \multicolumn{2}{|c|}{ Firm exit during the crisis } \\
\hline & Coefficient & Marginal effect \\
\hline \multirow{2}{*}{ Size } & -0.0663 & -0.001 \\
\hline & \multicolumn{2}{|c|}{$(-1.22)$} \\
\hline \multirow{2}{*}{ Age } & 0.088 & 0.0013 \\
\hline & \multicolumn{2}{|c|}{$(0.73)$} \\
\hline \multirow{2}{*}{ Prod } & -0.383 & -0.0058 \\
\hline & \multicolumn{2}{|c|}{$(-4.21) \mathrm{a}$} \\
\hline \multirow{2}{*}{ Export } & -1.535 & -0.0407 \\
\hline & \multicolumn{2}{|c|}{$(-8.46) \mathrm{a}$} \\
\hline \multirow{2}{*}{ Inwfdi } & 0.0359 & 0.0006 \\
\hline & \multicolumn{2}{|c|}{$(0.12)$} \\
\hline \multirow{2}{*}{ Outfdi } & 0.7219 & 0.0262 \\
\hline & \multicolumn{2}{|c|}{ (3.18)a } \\
\hline \multirow{2}{*}{ Collateral } & -0.4115 & -0.0063 \\
\hline & \multicolumn{2}{|c|}{$(-1.83) \mathrm{c}$} \\
\hline \multirow{2}{*}{ Profit } & 0.0017 & 0 \\
\hline & \multicolumn{2}{|c|}{$(0.69)$} \\
\hline \multirow{2}{*}{ Solvency } & -0.0069 & -0.0001 \\
\hline & \multicolumn{2}{|c|}{$(-1.84)^{*}$} \\
\hline \multirow{2}{*}{ Debts banks } & 0.0069 & 0.0001 \\
\hline & \multicolumn{2}{|c|}{ (2.74)a } \\
\hline \multirow{2}{*}{ Spec } & 0.0591 & 0.0009 \\
\hline & \multicolumn{2}{|c|}{$(0.40)$} \\
\hline \multirow{2}{*}{$\mathrm{RD}$} & -2.3882 & -0.0365 \\
\hline & \multicolumn{2}{|c|}{$(-1.23)$} \\
\hline \multirow{2}{*}{ Pavitt 1} & 0.4372 & 0.0073 \\
\hline & \multicolumn{2}{|c|}{$(0.85)$} \\
\hline \multirow{2}{*}{ Pavitt 3} & -0.1883 & -0.0027 \\
\hline & & $0.46)$ \\
\hline Pavitt 4 & -3.2184 & -0.0099 \\
\hline Favitu 4 & & 5.15)а \\
\hline Soutb location dummu & 0.0206 & 0.0003 \\
\hline south location dummy & & $0.13)$ \\
\hline Industry dummies (2 digit Ateco) & & Yes \\
\hline Number of observations & & 2441 \\
\hline Log likelihood & & 5.0667 \\
\hline Pseudo R2 & & 0.29 \\
\hline Pred. P (at x bar) & & .005 \\
\hline
\end{tabular}

\section{Conclusions}

Authors of current paper looked at the recent crisis highlighting the influence of internationalisation on firm survival in Italy, controlling for the role of several firms characteristics (size, age, productivity, financial health and innovation) and industry variables (specialisation, Pavitt classes).

To sum up, the results reveal the higher chances of survival for firms which export over the crisis, while uncovering the higher risk of failure faced by Italian firms investing abroad. However, foreign owned firms do not experience lower failure risk than domestic firms.
Firm financial profile also showed up as quite relevant for firm exit. In particular, lower collateral and solvency and higher debt towards banks over turnover had a positive and highly significant association with the probability of firm exit, which was not observed before the crisis. Our results also suggest that during the crisis small firms were not more at risk of exiting with respect to larger firms, after controlling for their performance in terms of exports, collateral guarantees and bank indebtedness.

To conclude, the findings for Italy and for our sample are not consistent with the idea that foreign multinational firms are more affected by an economic crisis and that they are more volatile than domestic firms in these circumstances. On the other hand, we do not get evidence neither that they are able to act as stabilizers, as some literature has shown (Desai et al. 2008; Blalock 2008; Tong, Wei 2010; Alfaro, Chen 2011). Finally, it has quite relevant policy implications the fact that exporting firms have experienced reduced exit probabilities both before and after the shock and that domestic multinationals have been more likely to exit over the crisis.

However, much more research is needed on the heterogeneous response of multinationals enterprises and of their affiliates to the impact of a crisis. Multinationals behaviour is influenced by a complex network of relationships. Therefore, responses of firms to changes in their domestic and international environment are not only a function of firm characteristics but also depend on complex ties and international linkages. The affiliates' position in the MNEs' network, the country of origin of investors and the investment motivations may indeed determine different outcome.

Further research should point to look for data which allow a disaggregation of the chain of relationships, both productive and financial, behind the multinationals' responses. Besides, as mentioned above, more research is needed on the behaviour of exporters in a crisis.

\section{Acknowledgements}

The authors owe special thanks to Umberto De Marco, Paolo Aliberti and Giovanna Casolino for for their precious support with AIDA and MintItaly data collection. We also thank Neil O'Higgins and Fernanda Mazzotta for useful comments and insights. The authors would like to thank seminar participants at the 2010 ETSG conference in Lausanne and at the 2011 SIE conference in Rome. 


\section{References}

Alfaro, L.; Chen, M. 2011. Surviving the global financial crisis: foreign direct investment and establishment performance. Working Paper, Harvard Business School: 10-110.

Alvarez, R.; Görg, H. 2009. Multinationals and plant exit: evidence from Chile, International Review of Economics and Finance 18(3): 45-51.

http://dx.doi.org/10.1016/j.iref.2008.02.011

Alvarez, R.; Görg, H. 2011. Multinationals as stabilisers? Economic Crisis, Access to Finance and Employment Growth. Working Paper, Kiel Institute for the World Economy. 38 p.

Antonioli, D.; Bianchi, A.; Mozzanti, M.; Montresor, S.; Pini, P. 2011. Economic Crisis, Innovation Strategies and Firm Performance. Evidence from Italian Firmlevel Data. Working Paper, Universita Degli Studi di Ferrara. Available from Internet:

http://out.economia.unife.it/uploads/dip_deit/quader ni/201102.pdf

Athukorala, P. 2003. FDI in crisis and recovery: Lessons from the 1997-1998 Asian crisis, Australian Economic Review 43(2): 197-213. http://dx.doi.org/10.1111/1467-8446.t01-1-00051

Audretsch, D. B.; Mahmood, T. 1995. New-Firm Survival: New Results using a Hazard Function, The Review of Economics and Statistics 77(1): 97-103. http://dx.doi.org/10.2307/2109995

Audretsch, D. B.; Houweling, P.; Thurik, A. 2000. Firm Survival in the Netherlands, Review of Industrial Organization 16(1): 1-11. http://dx.doi.org/10.1023/A:1007824501527

Barney, J. B.; Wright, M.; Ketchen Jr., D. J. 2001. The resource-based view of the firm: Ten years after 1991, Journal of Management 27(6): 625-641. http://dx.doi.org/10.1177/014920630102700601

Becchetti, L.; Trovato, G. 2002. The Determinants of Growth for Small and Medium Sized Firms: The Role of the Availability of External Finance, Small Business Economics 19(4): 291-306. http://dx.doi.org/10.1023/A:1019678429111

Bernard, A. B.; Sjöholm, F. 2003. Foreign owners and plant survival. Working Paper, National Bureau of Economic Research. Available in Internet: http://www.nber.org/papers/w10039.pdf

Blalock, G.; Gertler, P.; Levine, D. 2008. Financial constraints on investment in an emerging crisis, Journal of Monetary Economics 55: 568-591. http://dx.doi.org/10.1016/j.jmoneco.2008.01.005

Bottazzi, G.; Grazzi, M.; Secchi, A.; Tamagni, F. 2011a. Financial and economic determinants of firm default, Journal of Evolutionary Economics 21(3): 373-406. http://dx.doi.org/10.1007/s00191-011-0224-6

Bottazzi, G; Tamagni, F. 2011b. Big and fragile: when size does not shield from default, Applied Economics Letters: 1-4. http://dx.doi.org/10.1080/13504851.2010.539529

Bridges, S.; Guariglia, A. 2008. Financial constraints, global engagement, and firm survival in the United
Kingdom: evidence from micro data, Scottish Journal of Political Economy 55(4): 444-464.

http://dx.doi.org/10.1111/j.1467-9485.2008.00461.x

Bugamelli, M., Cristadoro, R.; Zevi, G. 2009. Questioni di Economia e Finanza. Occasional Papers 58, Bank of Italy, Economic Research Department. Available in Internet:

http://www.bancaditalia.it/pubblicazioni/econo/ques t_ecofin_2/QF_86/QEF_86.pdf

Bunn, P.; Redwood, V. 2003. Company Accounts Based Modelling of Business Failures and the Implications for Financial Stability. Discussion Paper 210, Bank of England.

Cingano, F.; Torrini, R.; Viviano, E. 2010. The crisis and employment in Italy. Questioni di Economia e Finanza. Occasional Papers 68, Bank of Italy, Economic Research Department.

Colombo, E. 2001. Determinants of corporate capital structure: evidence from Hungarian firms. Applied Economics 33(13): 1689-701. http://dx.doi.org/10.1080/00036840010015057

Desai, M. A.; Foley, C.; Forbes, K. J. 2008. Financial Constraints and Growth: Multinational and Local Firm Responses to Currency Depreciations, Review of Financial Studies 21(6): 2857-2888. doi: 10.1093/rfs/hhm017

Desai, M. ; Foley, F., Forbes, K. 2004. Financial Constraints and Growth: Multinational and Local Firm Responses to Currency Crises. Working Paper Nr. 10545, National Bureau of Economic Research. 19 p.

Disney, R.; Haskel, J.; Heden, Y. 2003. Entry, Exit and Establishment Survival in UK Manufacturing, Journal of Industrial Economics 51(2): 91-112. http://dx.doi.org/10.1111/1467-6451.00193

Dunne, T. ; Roberts, M. ; Samuelson, L. 1989. The Growth and Failure of US Manufacturing Plants, Quarterly Journal of Economics 104(4): 671-698. http://dx.doi.org/10.2307/2937862

Esteve Pérez, S.; Sanchis Llopis, A.; Sanchis Llopis, J. A. 2004. The Determinants of Survival of Spanish Manufacturing Firms, Review of Industrial Organization 25: 251-73. http://dx.doi.org/10.1007/s11151-004-1972-3

Fabiani, S.; Sabatini, R. 2011. Wage adjustment by Italian firms: any difference during the crisis? A survey-based analysis. Occasional Papers 94, Banca d'Italia. Available in Internet:

http://www.bancaditalia.it/pubblicazioni/econo/ques t_ecofin_2/QF_94/QEF_94.pdf

Ferragina, A.; Pittiglio, R.; Reganati, F. 2010. The Impact of FDI on Firm Survival in Italy, in Proceeding of the $6^{\text {th }}$ International Scientific Conference "Business and Management”, Vilnius, Lithuania, 13-14 May 2010. Selected papers. Vilnius: Technika, 2010, 60-68. ISBN 978-9955-28-311-9.

Ferragina, A. M.; Pittiglio, R.; Reganati, F. 2011. Multinational status and firm exit in the Italian manufacturing and service sectors, Structural Change and Economic Dynamics. http://dx.doi.org/10.1016/j.strueco.2011.10.002 
Flamm, K. 1984. The volatility of offshore investment, Journal of Development Economics 16(3): 231-248. http://dx.doi.org/10.1016/0304-3878

Fukao, K. 2001. How Japanese subsidiaries in Asia responded to the regional crisis - an empirical analysis based on the MITI survey, in Regional and global capital flows: Macroeconomics causes and consequences. Cambridge (MA): National Bureau of Economic Research. 392 p.

Fotopoulos, G.; Louri, H. 2000. Determinants of Hazard Confronting New Entry: Does Financial Structure Matter? Review of Industrial Organization 17(3): 285-300.

http://dx.doi.org/10.1023/A:1007862922531

Godart, O.; Görg, H.; Hanley, A. 2011. Surviving the crisis: Foreign multinationals vs domestic firms in Ireland, Working Paper Nr. DR8596, Centre for Economic Policy Research.

Görg, H.; Strobl, E. 2003. Footloose multinationals? The Manchester School 71(1): 1-19. http://dx.doi.org/10.1111/1467-9957.00331

Görg, H.; Spaliara, M. E. 2009. Financial health, exports and firm survival: A comparison of British and French firm. Discussion Paper Nr. 1568, Kiel Institute for the World Economy.

Greenaway, D.; Guariglia, A.; Kneller, R. 2007. Financial factors and exporting, Journal of International Economics 73(2): 377-395. http://dx.doi.org/10.1016/j.jinteco.2007.04.002

Greenaway, D.; Gullstrand, J.; Kneller, R. 2008. Surviving globalisation, Journal of International Economics 74(2): 264-277. http://dx.doi.org/10.1016/j.jinteco.2007.08.005

Guariglia, A.; Mateut, S. 2005. Inventory investment, global engagement and financial constraints in the UK: evidence from micro data. Research Paper Nr. 05/23, Leverhulme Centre for Research on Globalization and Economic Policy, University of Nottingham.

Harrison, A.; McMillan, M. 2003. Does Direct Foreign Investment Affect Domestic Firms Credit Constraints? Journal of International Economics 61(1): 73-100. http://dx.doi.org/10.1016/S00221996(02)00078-8

Hopehayn, R. 1992. Entry, exit and firm dynamics in long run equilibrium, Econometrica 60: 1127-1155. http://dx.doi.org/10.2307/2951541

Jovanovic, B. 1982. Selection and evolution of industry, Econometrica 50: 3-37. http://dx.doi.org/10.2307/1912606

Kimura, F.; Fujii, T. 2003. Globalizing activities and the rate of survival: panel data analysis on Japanese firms, Journal of Japanese International Economies 17(2): 538-560.

http://dx.doi.org/10.1016/j.jjie.2003.08.003

Lipsey, R. 2001. Foreign investment in three financial crisis. Working Paper Nr. 8084, Cambridge (MA): National Bureau of Economic Research.

Mata, J.; Portugal, P. 1994. Life duration of new firms, Journal of Industrial Economics 42(3): 227-246. http://dx.doi.org/10.2307/2950567
McAleese, D.; Counahan, M. 1979. Stickers or snatchers? Employment in multinational corporations during recessions, Oxford Bulletin of Economics and Statistics 41: 345-358. http://dx.doi.org/10.1111/j.14680084.1979.mp41004007.x

Melitz, M. J. 2003. The Impact of Trade on Intra-Industry Reallocations and Aggregate Industry Productivity, Econometrica 71(6): 1695-1725. http://dx.doi.org/10.1111/1468-0262.00467

Narjoko, D.; Hill, H. 2007. Winners and losers during a deep economic crisis: Firm-level evidence from Indonesian manufacturing, Asian Economic Journal 21(4): 343-368. http://dx.doi.org/10.1111/j.14678381.2007.00261.x

Ozler, S.; Taymaz, E. 2004. Foreign Ownership, Competition, and Survival Dynamics, Review of Industrial Organization 31(1): 23-42.

Sato, Y. 2000. How did the crisis affect small and medium sized enterprises? From a field study of the metal-working industry in Java, The Developing Economies 38(4): 572-595.

http://dx.doi.org/10.1111/j.1746-

1049.2000.tb00891.x

ter Wengel, J., Rodriguez, E. 2006. SME export performance in Indonesia after the crisis, Small Business Economics 26(1): 25-37. http://dx.doi.org/10.1007/s11187-004-6491-y

Tong, H.; Wei, S. J. 2010. The Composition Matters: Capital Inflows and Liquidity Crunch During A Global Economic Crisis, Working Paper Nr. 17/2010, Hong Kong Institute For Monetary Research.

Vartia, L. 2004. Assessing Plant Entry and Exit Dynamics and Survival - Does Firms' Financial Status Matter? Mimeograph, European University Institute.

Varum, C. A.; Rocha, V. C. 2011. Do foreign and domestic firms behave any different during economic slowdowns? International Business Review 20(1): 48-59. http://dx.doi.org/10.1016/j.ibusrev.2010.06.001

Wagner, J. 1994. The Post-entry Performance of New Small Firms in German Manufacturing Industries, Journal of Industrial Economics 42(2): 141-54. http://dx.doi.org/10.2307/2950486

Wagner, J. 2011. Exports, Imports and Firm Survival: First evidence for manufacturing enterprises in Germany, Working Paper Nr. 5924, University of Lüneburg.

Wang, H.; Huang, H.; Bansal, P. 2005. What determined success during the Asian economic crisis? The importance of experiential knowledge and group affiliation, Asia Pacific Journal of Management 22(1): 89-106. http://dx.doi.org/10.1007/s10490-005-6419-3

Zingales, L. 1998. Survival of the Fittest or the Fattest? Exit and Financing in Trucking Industry, Journal of Finance 53(3): 905-993. http://dx.doi.org/10.1111/0022-1082.00039 